\title{
Effect of feeding cholesterol-enriched diet on plasma and tissue cholesterol and atherosclerosis in rabbits
}

\author{
Anna M. Konecka, T. Jezierski and Agata Wnuk \\ Institute of Genetics and Animal Breeding, \\ Polish Academy of Sciences \\ Jastrzębiec, 05-55I Mroków, Poland
}

(Received 3 November 1995; accepted 12 April 1996)

\begin{abstract}
The aim of the experiment was to investigate the relationship between consumption of cholesterolenriched diet and plasma and tissue cholesterol content as well as the degree of atherosclerosis in rabbits, to make further investigations on the role of emotional and behavioural factors in diet induced atherosclerosis more conclusive. The experimental rabbits (E) were offered $150 \mathrm{~g}$ standard pellet feed daily mixed with $1 \mathrm{egg}$ yolk and $1.5 \mathrm{~g}$ cholesterol in substantia during 7 weeks, whereas the control rabbits (C) were fed the same amount of feed without egg yolk and supplementary cholesterol. Significant effect of diet type on total plasma cholesterol, HDL-cholesterol (high density lipoprotein cholesterol) and cholesterol content in liver, heart and muscle was found. However negative correlations between cholesterol food consumption and total plasma cholesterol $(r=-0.24)$ and atherosclerosis $(r=-0.40)$ were found in group $E$. The relative increase of total plasma cholesterol in $\mathrm{E}$ group was greater than that of plasma HDL-cholesterol. Females demonstrated significantly higher total plasma cholesterol and HDL-cholesterol than males. The degree of atherosclerosis was positively correlated with the total plasma cholesterol $(\mathrm{r}=0.73, \mathrm{P}<0.01)$ and plasma HDL-cholesterol concentration $(r=0.29)$ but negatively correlated with ratio HDL/total cholesterol $(r=-0.66, P<0.01)$ as estimated after the end of the experiment.
\end{abstract}

KEY WORDS: feeding, plasma cholesterol, HDL-cholesterol, tissue cholesterol, atherosclerosis, rabbits

\section{INTRODUCTION}

Dietary cholesterol consumed in large amounts is believed to increase plasma cholesterol which in turn may raise risk of atherosclerosis. Moreover, the 
absorption of high amounts of cholesterol from blood and its accumulation in liver probably may impair liver function (Beynen et al., 1986).

In the previous experiments we used rabbits as experimental models for investigation emotional and behavioural factors playing a role in diet induced atherosclerosis. These factors turned out to be biologically not neutral but are often unpredictable (Jezierski et al., 1993). To make these factors more discernible we tried to control individual differences in cholesterol feed consumption and to induce only a moderate atherosclerosis. We found no significant effect of feeding egg yolk on plasma cholesterol and development of atherosclerosis in rabbits (Jezierski and Konecka, 1994). In the present experiment apart from egg yolk supplementary cholesterol was added to rabbit standard diet in order to induce atherosclerosis. Relationship between cholesterol food consumption and primary plasma cholesterol content, the increase of plasma cholesterol and cholesterol content in liver, heart, muscle as well as the atherosclerosis were investigated. Particular attention was paid to differences between sexes. The results of the present experiment should help us to find the optimal experimental set-up for further experiments on the role of emotional and behavioural factors in diet induced atherosclerosis.

\section{MATERIAL AND METHODS}

Forty White New Zealand rabbits (23 males and 17 females) stemming from Institute's own outbred stock were used. The animals were three months old with an average body weights $3.65 \mathrm{~kg}$ for males and $3.77 \mathrm{~kg}$ for females at the beginning of the experiment. The rabbits were kept in individual wire cages $60 \mathrm{~cm} \times 60 \mathrm{~cm} \times 32 \mathrm{~cm}$ at the average room temperature of $14-18^{0} \mathrm{C}$. After weaning, till the begining of the experiment the rabbits were fed ad libium with standard pelleted rabbit feed containing $18.0 \%$ crude protein, $4.2 \%$ fat (bone-meat meal) and $13.1 \%$ crude fibre and $98(\mathrm{SD}=7.2) \mathrm{mg}$ cholesterol $/ 100 \mathrm{~g}$ dry feed. Water was available ad libitum.

The experiment lasted seven weeks. During that time the experimental rabbits $(\mathrm{E}, \mathrm{n}=22)$ were offered $150 \mathrm{~g}$ standard feed daily mixed with 1 egg yolk and 1.5 $\mathrm{g}$ cholesterol in substantia, except for Saturdays and Sundays when they received standard feed only. The control rabbits $(\mathrm{C}, \mathrm{n}=18)$ received the same amount of feed but without egg yolk and without supplementary cholesterol. Since the rabbits sometimes did not consume their full daily dose, the refuse was weighted daily. All the rabbits were weighted weekly.

Before and after the experimental period blood samples were taken into heparinized tubes from an ear vein. Prior to blood sampling the rabbits were fasted for $24 \mathrm{~h}$. After collection the blood samples were centrifuged at $3000 \mathrm{xg}$ for 
15 min at $+4^{\circ} \mathrm{C}$. Plasma total cholesterol content in $\mathrm{mg} / 100 \mathrm{ml}$ was determined using Biochemtest No. 1344-690-718061 (POCh, Gliwice, Poland). The estimation of total cholesterol for each sample was repeated 3 times the intra assay variability being $2 \%$. Plasma HDL cholesterol was measured after precipitation of VLDL (very low density lipoprotein) and LDL (low density lipoprotein) with phosphotungstate/magnesium chloride at room temperature.

After killing each rabbit, the aorta ascendens, arcus aortae and aorta descendens up to the 6 th or 7 th arteria intercostalis were cut out and dissected. These arteries were stained with oil-red O (Romeis, 1968), pinned out and photographed in colour. Two colours tints were distinguised: (a) deep red indicating severe atheroma and (b) pink or pale indicating weak or no atheroma. Atheroma size was estimated by placing a transparent grid over the photograph, counting the deep red squares and presenting them as percentage of the total number of counted squares.

The liver, heart and muscle were removed and frozen at $-20^{\circ} \mathrm{C}$, until used. The cholesterol was extracted from organs using the chloroform-metanol mixture $(2: 1, \mathrm{v} / \mathrm{v})$ extraction procedure of Folch et al. (1957) and Rhee et al.(1982). Cholesterol was determined according to the colorimetric method of Searcy and Bergquist (1960). The results were expressed as $\mathrm{mg} / 100 \mathrm{~g}$ of tissue.

\section{Statistical analysis}

For the statistical analyses the following mixed model of two-way ANOVA was used:

where: $u \quad-$ mean value

$$
Y(i j k)=u+D(i)+S(j)+D S(i j)+e(i j k)
$$

$D(i)$ - effect of diet $(i=1,2)$ - fixed effect

$\mathrm{S}(\mathrm{j}) \quad$ - effect of sex $(\mathrm{j}=1,2)$ - random effect

DS(ij) - effects of diet $x$ sex interaction

e(ijk) - error

Prior to the ANOVA ( analysis of variance) the data on atherosclerosis degree and ratio $\mathrm{HDL} /$ Total plasma cholesterol were transformed using $\arcsin \sqrt{\mathrm{p}}$.

The linear correlation coefficients between the traits investigated were calculated.

\section{RESULTS}

Rabbits in the control group as well as the females in both $\mathrm{E}$ and $\mathrm{C}$ groups tended to consume more feed. However these differences did not reach the significance level (Table 1). 
TABLE 1

Feed consumption (g) in rabbits during the experimental period and degree of atherosclerosis, $\%$ of aorta surface

\begin{tabular}{|c|c|c|c|c|c|c|c|c|}
\hline & \multicolumn{4}{|c|}{ Experimental group } & \multicolumn{4}{|c|}{ Control group } \\
\hline & $\mathbf{n}$ & mean & SEM & atheroscler & $\mathrm{n}$ & mean & SEM & atheroscler \\
\hline males & 12 & 6681 & 208.1 & 45.7 & 11 & 6872 & 158.4 & 0 \\
\hline females & 10 & 6919 & 171.9 & 71.8 & 7 & 7236 & 44.1 & 0 \\
\hline total & 22 & 6789 & 642.9 & 57.6 & 18 & 7014 & 448.9 & 0 \\
\hline
\end{tabular}

Results of ANOVA

Source of variation

Significance of $\mathbf{F}$

Feed consumption

Atherosclerosis (for $\mathbf{E}$ group only, data transformed)

$\begin{array}{lcc} & \text { df } & \\ \operatorname{diet} & 1 & 0.168 \\ \text { sex } & 1 & 0.104 \\ \text { diet } x \text { sex } & 1 & 0.730\end{array}$

0.073

Plasma total cholesterol concentration significantly increased in group $\mathrm{E}$ after the experiment $(\mathrm{P}<0.000)$, whereas a moderate decrease in the $\mathrm{C}$ group was observed (Table 2). Females had higher total plasma cholesterol than males especially after the experiment $(\mathrm{P}=0.032$; Table 2$)$. The same holds for the

TABLE 2

Total plasma cholesterol in $\mathrm{mg} / 100 \mathrm{ml}$ of blood plasma before and after the experimental period

\begin{tabular}{lrrrrrrr}
\hline & \multicolumn{3}{c}{ Before experiment } & & \multicolumn{2}{c}{ After experiment } \\
\cline { 2 - 3 } & $\mathrm{n}$ & mean & SEM & & mean & SEM \\
\hline Experimental group & 12 & 134.6 & 12.9 & & 636.2 & 109.8 \\
$\quad$ males & 10 & 160.1 & 11.9 & & 947.2 & 91.8 \\
$\quad$ females & 22 & 146.2 & 9.1 & & 777.5 & 79.1 \\
$\quad$ total group E & 11 & 140.7 & 9.5 & & 60.7 & 3.6 \\
Control group & 7 & 151.9 & 10.9 & & 118.8 & 14.8 \\
$\quad$ males & 18 & 145.1 & 7.1 & & 83.3 & 9.1 \\
$\quad$ females & & & & & & \\
$\quad$ total group C & & & & & & &
\end{tabular}

Results of ANOVA

Source of

Significance of $\mathrm{F}$

variation

diet

df

sex

$1 \quad 0.993$

0.000

diet $x$ sex

0.135

0.032

$\begin{array}{ll}1 & 0.557\end{array}$

0.130 
TABLE 3

Plasma HDL-cholesterol in $\mathrm{mg} / 100 \mathrm{ml}$ of blood plasma and ratio $\mathrm{HDL} /$ total cholesterol before and after the experimental period

\begin{tabular}{|c|c|c|c|c|c|c|c|}
\hline & \multicolumn{4}{|c|}{ Before experiment } & \multicolumn{3}{|c|}{ After experiment } \\
\hline & $\mathrm{n}$ & mean & SEM & HDL/t.chol. & mean & SEM & $\mathrm{HDL} / \mathrm{t}$.chol. \\
\hline \multicolumn{8}{|c|}{ Experimental group } \\
\hline males & 12 & 63.0 & 5.0 & .508 & 75.1 & 10.6 & .214 \\
\hline females & 10 & 74.8 & 5.4 & .477 & 94.1 & 6.5 & .113 \\
\hline total group E & & 68.4 & 3.8 & .494 & 83.8 & 6.7 & .168 \\
\hline \multicolumn{8}{|l|}{ Control group } \\
\hline males & 11 & 67.0 & 9.0 & .479 & 45.7 & 6.0 & .755 \\
\hline females & 7 & 93.4 & 7.1 & .626 & 70.2 & 5.9 & .619 \\
\hline total group C & & 77.3 & 6.8 & .536 & 55.2 & 5.1 & .702 \\
\hline
\end{tabular}

Results of ANOVA

Source of

Significance of $\mathbf{F}$

variation

$\begin{array}{llllll}\text { diet } & 1 & 0.115 & 0.390 & 0.003 & 0.000 \\ \text { sex } & 1 & 0.010 & 0.212 & 0.013 & 0.296 \\ \text { diet x sex } & 1 & 0.310 & 0.077 & 0.741 & 0.490\end{array}$

HDL-cholesterol concentration, however, the changes in HDL-cholesterol concentration after vs. before the experiment were relatively smaller (Table 3). The ratio HDL/Total plasma cholesterol decreased in group $\mathrm{E}$ after the experiment and increased in group $\mathrm{C}$ (in males only).

Intake of cholesterol-enriched diet resulted in almost three-fold increase of hepatic cholesterol and two-fold increase of heart and muscle cholesterol concentration in group $\mathrm{E}$ as compared to control animals $(P=0.000$; Table 4$)$.

The correlation coefficients between cholesterol feed consumed in group $\mathrm{E}$ and cholesterol content in plasma and tissues were negative and nonsignificant (Table 5).

Rabbits of the E group developed severe atherosclerosis after feeding with cholesterol-enriched diet, whereas no symptoms of atherosclerosis were ascertained in the group C. Typical aorta with and without atherosclerosis is shown on Figure 1. Females developed more severe atherosclerosis (on average 71.8 $\%$ aorta surface) than males $(45.7 \%)$ but this difference did not reach the significance level (Table 1). The correlation between cholesterol feed consumed in group $\mathrm{E}$ and the degree of atherosclerosis was negative $(\mathrm{r}=-0.4)$. The degree of atherosclerosis was positively correlated with total plasma cholesterol concentration $(\mathrm{r}=0.73 ; \mathrm{P}<0.01)$ and negatively correlated with the ratio HDL/total plasma cholesterol after the experiment $(r=-0.66 ; P<0.01$, Table 5). 
TABLE 4

Cholesterol content $(\mathrm{mg} / 100 \mathrm{~g})$ in rabbit tissues

\begin{tabular}{|c|c|c|c|c|c|c|c|}
\hline \multirow{2}{*}{ Insminagrs rofin } & \multicolumn{3}{|c|}{ Liver } & \multicolumn{2}{|c|}{ Heart } & \multicolumn{2}{|c|}{ Muscle } \\
\hline & $\mathrm{n}$ & mean & SEM & mean & SEM & mean & SEM \\
\hline \multicolumn{8}{|l|}{ Experimental group } \\
\hline males & 12 & 1073.0 & 112.6 & 295.3 & 34.5 & 117.3 & 13.9 \\
\hline females & 1.10 & 1276.3 & 39.7 & 311.8 & 18.5 & 164.1 & 16.5 \\
\hline total group E & I.AP & 1165.4 & 66.9 & 302.8 & 20.6 & 138.6 & 11.6 \\
\hline Control group & 8.88 & mets. & 8.6 & 4.82 & & $3 q$ & oxy lestos \\
\hline males & 11 & 385.2 & 29.7 & 162.0 & 5.3 & 77.6 & 8.7 \\
\hline females & 7 & 434.0 & 43.1 & 160.6 & 11.2 & 77.7 & 8.4 \\
\hline total group C & 5.05 & 404.2 & 24.1 & 161.5 & 5.4 & 77.7 & 5.5 \\
\hline
\end{tabular}

Results of ANOVA

Source of variation

diet

sex

diet $\mathrm{x} \operatorname{sex}$

$$
\text { df }
$$

$1 \quad 0.000$

10.106

10.316

Significance of $F$

$\begin{array}{ll}0.000 & 0.000 \\ 0.757 & 0.086 \\ 0.714 & 0.088\end{array}$
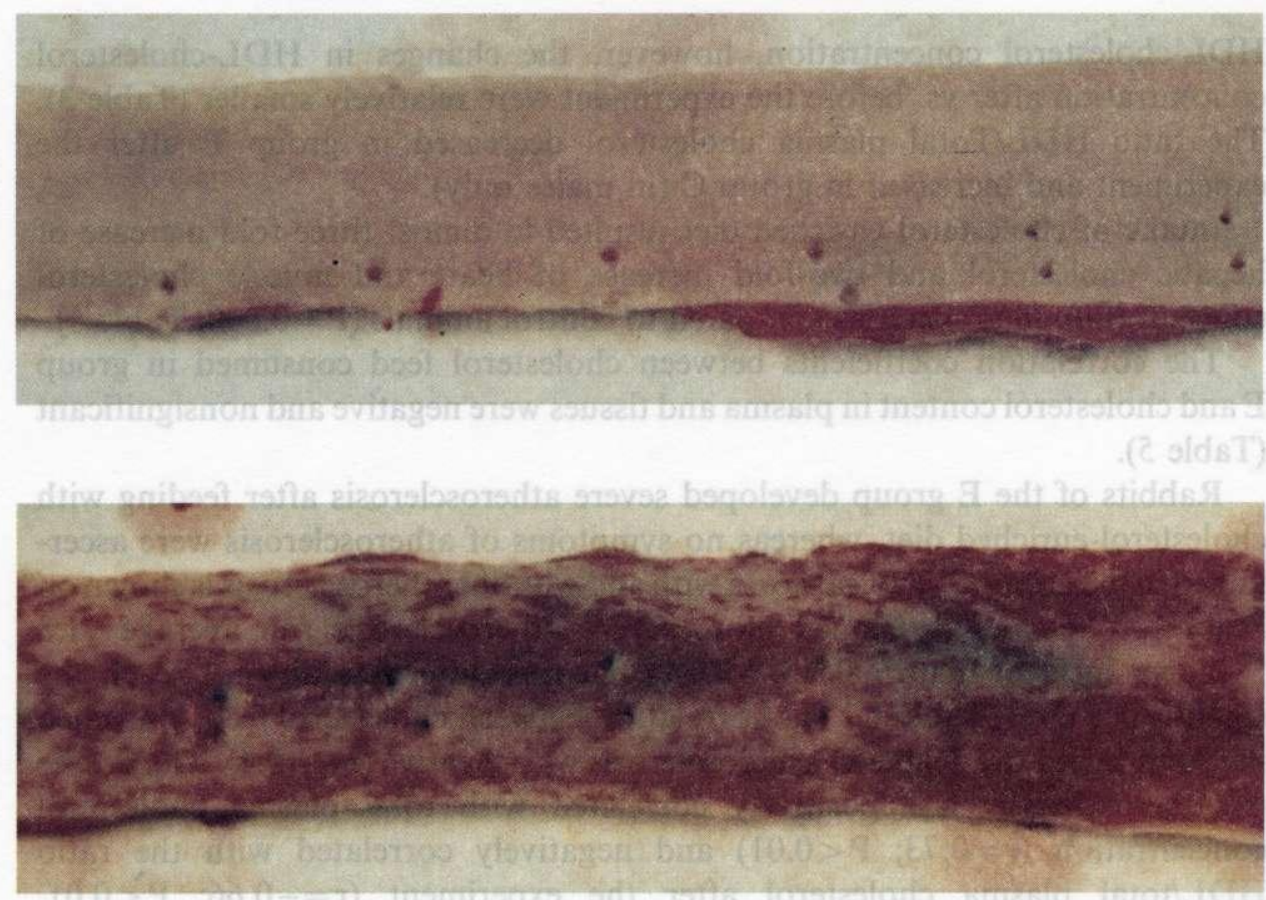

Figure 1. Typical aortas of rabbits without (a) and with (b) atherosclerosis 
TABLE 5

Correlation coefficients between traits investigated (Experimental group $n=22$, Control group $\mathrm{n}=18$ )

\begin{tabular}{|c|c|c|c|c|c|c|c|c|c|c|}
\hline \multicolumn{11}{|c|}{ trait number } \\
\hline & 2 & 3 & 4 & 5 & 6 & 7 & 8 & 9 & 10 & 11 \\
\hline 1. E & -.44 & -.24 & .20 & .02 & .45 & .25 & -.22 & -.23 & -.09 & -.40 \\
\hline $\mathrm{C}$ & .02 & .33 & .39 & .41 & .44 & .09 & -.37 & .11 & .01 & \\
\hline 2. $\mathrm{E}$ & & .37 & .39 & .14 & $-.61^{*}$ & -.36 & .47 & .26 & .27 & .43 \\
\hline $\mathrm{C}$ & & .12 & .48 & .42 & -.10 & .19 & .05 & .09 & -.11 & \\
\hline 3. $\mathrm{E}$ & & & .20 & $.54^{*}$ & -.14 & $-.79^{* *}$ & $.66^{* *}$ & $.71^{* *}$ & * $.51 *$ & $.73^{* *}$ \\
\hline $\mathrm{C}$ & & & .43 & $.60^{*}$ & .44 & -.37 & .38 & .16 & .19 & \\
\hline 4. $E$ & & & & .25 & .43 & .02 & .31 & .08 & .30 & .19 \\
\hline $\mathrm{C}$ & & & & .52 & $.81^{* *}$ & .02 & .25 & .05 & .35 & \\
\hline 5. E & & & & & .04 & -.36 & $.83^{* *}$ & .48 & .23 & .29 \\
\hline $\mathrm{C}$ & & & & & .31 & .44 & -.01 & .23 & .36 & \\
\hline 6. E & & & & & & .36 & -.17 & -.18 & -.09 & -.19 \\
\hline $\mathrm{C}$ & & & & & & -.14 & .26 & .02 & .44 & \\
\hline 7. $\mathrm{E}$ & & & & & & & $-.64 * *$ & -.46 & -.48 & $-.66^{* *}$ \\
\hline $\mathrm{C}$ & & & & & & & -.48 & .02 & .18 & \\
\hline 8. E & & & & & & & & .45 & .36 & $.56^{*}$ \\
\hline $\mathrm{C}$ & & & & & & & & .03 & .04 & \\
\hline 9. E & & & & & & & & & .47 & .47 \\
\hline C & & & & & & & & & -.05 & \\
\hline 10. E & & & & & & & & & & $.56^{*}$ \\
\hline
\end{tabular}

Trait numbers

1. Feed consumed during the experiment

2. Total plasma cholesterol before the experiment

3. Total plasma cholesterol after the experiment

4. Plasma HDL-cholesterol before the experiment

5. Plasma HDL-cholesterol after the experiment

6. Ratio HDL/Total plasma cholesterol before the experiment

7. Ratio HDL/Total plasma cholesterol after the experiment

8. Liver cholesterol

9. Heart cholesterol

10. Muscle cholesterol

11. Atherosclerosis degree 


\section{DISCUSSION}

As expected the rabbits fed with cholesterol-enriched diet, generally responded with significant elevation of cholesterol level in plasma and in all tissues investigated. This is consistent with results obtained by many authors on different species (Beynen et al., 1986; Grundy and Denecke, 1990; Jonnalagadda et al., 1993; Richard et al., 1990; Zhang et al., 1994). Rather unexpected however was the ascertained negative correlation between the amount of cholesterol feed consumed and cholesterol content in plasma, tissues and degree of atherosclerosis, as calculated on individual data in the group $\mathrm{E}$. This would mean that consumption of greater amounts of cholesterol may not result in more atherosclerosis. The negative correlation may also be interpreted as a tendency in rabbits with a higher primary level of plasma total cholesterol to consume spontaneously less feed containing supplementary cholesterol. This may be regarded as a behavioural mechanism preventing diet induced atherosclerosis. The observed decrease of plasma total cholesterol and HDL-cholesterol in control group after the experimental period may be explained by possible seasonal variation in cholesterol level in animals, which was reported by some authors (e.g. Kristal-Boneh et al., 1993).

In our experiment the females demonstrated generally higher level of cholesterol especially in the group fed with cholesterol enriched diet and consequently more severe atherosclerosis. The gender differences in this respect seem to be very interesting and were confirmend by some authors. Van Ree et al. (1994) indicated that female mice had doubled serum cholesterol as compared to males and were more susceptible to develop atherosclerosis while on atherogenic diet. Similarily to our results Roberts et al. (1974) reported higher total cholesterol in female rabbits. Cobb et al. (1993) found higher HDL cholesterol in women. Apart of this the latter authors found a higher fall in HDL cholesterol in females, following the crossover from a low to high polyunsaturated to saturated fat diet. On the contrary, Lind et al. (1990) did not find any remarkable sex dependent differences with respect to HDL cholesterol in hyperlipidemic rabbits.

The highest increase of cholesterol content in the liver as compared to other tissues is not surprising as the accumulation of cholesterol from the diet takes places first of all in the liver and to a lesser degree in other tissues (Richard et al., 1990; Zhang et al., 1994). On the other hand in comparison of different organs and tissues in some animal species, liver did not contain the highest cholesterol level in all cases (Park et al., 1991). The liver cholesterol level in our C rabbits was comparable to that in hamsters with normal level of cholesterol in the plasma and in our $\mathrm{E}$ rabbits was comparable to that in hamsters with spontaneous high level of plasma cholesterol (Sicart et al., 1984). 
Hypercholesterolemia is generally recognized as a risk factor for the atherosclerosis in several species (Tsuda et al., 1983; Remy,1993; van Ree et al., 1994). This was confirmed by positive and significant correlations between total plasma cholesterol and atherosclerosis degree in our experiment. Paigen et al. (1985) found much lower correlation $(r=0.29)$ between the total cholesterol level and susceptibility to lesions formation in the aortic wall in mice.

The results of the present experiment support the concept of the protective nature of the HDL-cholesterol as suggested by several authors for humans (Gordon et al., 1989) and other species (Liu et al., 1994). Of importance is the ratio HDL/total plasma cholesterol which was negatively correlated with the degree of atherosclerosis.

In conclusion, the diet induced atherosclerosis only roughly depends on cholesterol feed consumed as demonstrated by differences between the $\mathrm{E}$ and $\mathrm{C}$ groups and the negative correlation between amount of feed consumed and atherosclerosis degree in the E group. Taking into account the great individual variability in atherosclerosis degree and relationships between total plasma cholesterol, HDL cholesterol and atherosclerosis, for experiments on factors playing a role in diet induced atherosclerosis, we suggest to use animals with similar primary level of cholesterol.

\section{ACKNOWLEDGEMENT}

We are grateful to Mrs. Anna Stawicka for her care for the experimental animals.

\section{REFERENCES}

Beynen A.C., Danse L.H.J.C., van Leeuven F.X.R., Speijers G.J.A., 1986. Cholesterol metabolism and liver pathology in inbred strains of rats fed a high-cholesterol, high-cholate diet. Nutr. Rcp. Int. 34, 1079-1087

Cobb M., Greenspan J., Timmons M., Titelbaum H., 1993. Gender differences in lipoprotein responses to diet. Ann. Nutr. Metab. 37, 225-236

Folch J., Lees M., Soane Stanley G.H., 1957. A simple method for the isolation and purification of total lipides from animal tissues. J. Biol. Chem. 226, 497-509

Gordon D., Rifkind R.M., 1989. Current concepts: high-density lipoproteins - the clinical implications of recent studies. N. Engl. J. Med. 321, 1311-1315

Grundy S.M., Deneke M.A., 1990. Dictary influences on serum lipids and lipoproteins. J. Lipid. Res. $31,1149-1172$

Jezierski T., Mekking P., Wiepkema P.R., 1993. Handling and diet induced atherosclerosis in rabbits. Lab. Anim. 27, 235-239 
Jezierski T., Konecka A.M., 1994. Effect of feeding egg yolk on total plasma cholesterol and atherosclerosis in young rabbits. J. Anim. Feed Sci. 3, 317-324

Jonnalagadda S.S., Thye F.W., Robertson J.L., 1993. Plasma total and lipoprotein cholesterol, liver cholesterol and fecal cholesterol excretion in hamsters fed fiber diet. J.Nutr. 123, 1377-1382

Kristal-Boneh E., Harari G., Green M.S., 1993. Circannual variations in blood cholesterol levels. Chronobiol. Internat. 10, 37-42

Lind B.M., Littbarski R., Hohlbach G., Mller K.O.,1990. Long-term investigations of serum cholesterol, serum trigliceride, and HDL cholesterolin heritable hyperlipidemic rabbits. $Z$. Versuchstierkd. 33, 245-249

Liu A.C., Lawn R.M., Verstuyft J.G., Rubin E.M., 1994. Human apolipoprotein A-I prevents atherosclerosis associated with apolipoprotein[a] in transgenic mice. J. Lipid Res. 35, 2263-2267

Paigen B., Morrow A., Brandon C., Mitchell D., Holmes P., 1985. Variation in susceptibiliy to atherosclerosis amoung inbred strains of mice. Atherosclerosis 57, 65-73

Park Y.W., Kouassi M.A., Chin K.B., 1991. Moisture, total fat and cholesterol in goat organ and muscle meat. J.Food.Sci. 56, 1191-1193

Ree van J.H., van den Brock W.J.A.A., Dahlmans V.E.H., Groot P.H.E., Vidgeon-Hart M., Frants R.R., Wieringa B., Havekes L.M., Hofker M.H., 1994. Diet-induced hypercholesterolemia and atherosclerosis in heterozygous apolipoprotein $\mathrm{E}$ deficient mice. Atherosclerosis 111, 25-37

Rhee K.S., Dutson T.R., Smith G.C., Hostetler R.L., Reiser R. 1982. Cholesterol content of raw and cooked beef longissimus muscle with different degree of marbling. J. Food Sci. 47, 716-719

Richard M.J., Davis L.D., Jacobson N.L., 1990. The domestic goat: a useful model to determine effects of diet and exercise on cholesterol accumulation in the body. Comp. Biochem. Physiol. 95A, 275-280

Roberts D.C.K., West C.E., Redgrave T.G., Smith J.B., 1974. Plasma cholesterol concentration in normal and cholesterol-fed rabbits. Its variation and heritability. Atherosclerosis 19, 369-380

Romeis B., 1968. Mikroskopische Technik. Munchen-Wien R. Olderung Verlag, pp. 259

Searcy R.L., Bergquist L.M., 1960. A new color reaction for quantitation of serum cholesterol. Clin. Chim. Acta. 5, 192-199

Sicart R., Sable-Amplis R., Giuro A., 1984. Comparative studies of the circulating lipoproteins in hamster (Mesocricetus auratus) with a normal or spontaneous high level of cholesterol in the plasma. Comp. Biochem. Physiol. 78A, 511-514

Tsuda M., Kitazaki T., Imai Y., 1983. Changes in the profiles of rodent plasma lipoproteins and apolipoproteins after cholesterol feeding. J. Biochem. 93, 1071-1077

Zhang S., Wong W.W., Hachey D.L., Pond W.G., Lein P.D., 1994. Dietary cholesterol inhibits whole body but not cerebrum cholesterol synthesis in young pigs. J. Nutr. 124, 717-725

\section{STRESZCZENIE}

Wplyw diety wzbogaconej cholesterolem na poziom cholesterolu w osoczu krwi i tkankach oraz arteriosklerozę u mlodych królików

Celem pracy było zbadanie zależności pomiędzy ilością spożytej paszy wzbogaconej cholesterolem a poziomem cholcsterolu calkowitego i HDL-cholesterolu w osoczu krwi, tkankach (wątroba, serce, mięsień) oraz stopniem arteriosklerozy u królików. Ponadto celem doświadczenia było określenie optymalnych metod i uwarunkowań ilościowego wywoływania arteriosklerozy u królików dla badań nad rolą czynników emocjonalnych i behawioralnych w tym zakresie. Grupa 
doświadczalna (E) byla żywiona standardową paszą granulowaną (150 g/dzień), z dodatkiem 1 żóltka jaja kurzego oraz 1,5 g cholesterolu in substantia w ciągu 7 tygodni. Zwierzęta kontrolne (C) otrzymywaly w tym samym okresie jedynie paszę standardową. Stopień arteriosklerozy określano w procentach powierzchni aorty ze zmianami sklerotycznymi. U królików z grupy (E) stwierdzono istotny wzrost poziomu cholesterolu całkowitego i HDL-cholesterolu w osoczu oraz cholesterolu w badanych tkankach, przy czym stosunkowo najwięcej wzrósł poziom cholesterolu całkowitego w osoczu, zaś zmniejszył się stosunek HDL:Cholesterol całkowity. Poziom cholesterolu całkowitego i HDL-cholesterolu był istotnie wyższy u samic w porównaniu z samcami. W grupie doświadczalnej poziom cholesterolu całkowitego w osoczu i stopień arteriosklerozy był ujemnie skorelowany z ilością spożytej paszy. Poziom cholesterolu całkowitego w osoczu krwi i tkankach po okresie żywienia paszą $z$ cholesterolem był dodatnio skorelowany ze stopniem arteriosklerozy. Stopień arteriosklerozy byl zależny od wzajemnych relacji HDL i cholesterolu calkowitego w osoczu krwi. 